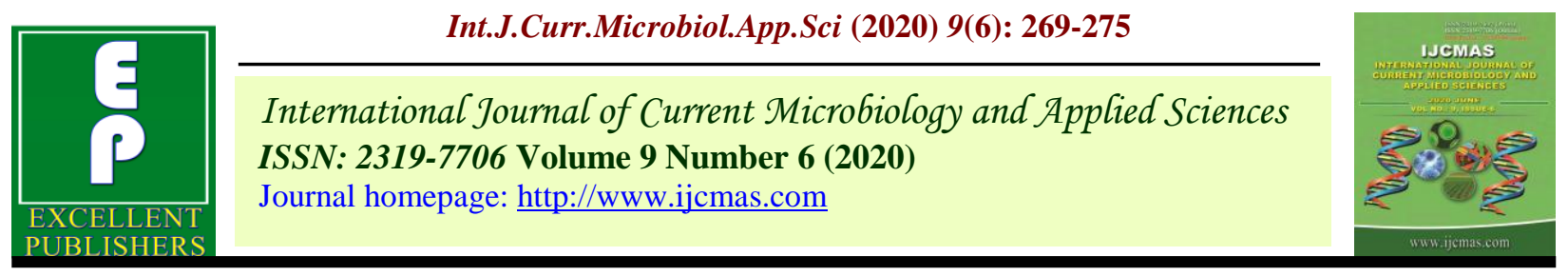

Original Research Article

https://doi.org/10.20546/ijcmas.2020.906.034

\title{
Intraclonal Variation in Musa (AAB) Palayankodan
}

\author{
C. Rajamanickam* and K. Rajmohan \\ Department of Horticulture, Agricultural College and Research Institute, \\ Madurai-625 104, Tamil Nadu, India \\ *Corresponding author
}

\begin{abstract}
A B S T R A C T
Keywords

Banana,

Palayankodan,

Motta Poovan,

PKNNR,

Vellapalayankodan

Article Info

Accepted:

14 May 2020

Available Online:

10 June 2020

The present investigation on Intraclonal variation in Musa (AAB) 'Palayankodan' was conducted at Instructional Farm, College of Agriculture, Vellayani, Thiruvananthapuram with assessing the performance of different palayankodan ecotypes with respect to growth, yield and quality was aimed at. The present study results revealed that Vellapalayankodan recorded the highest values in the vegetative traits like plant height $(417.2 \mathrm{~cm})$, pseudostem girth $(96.10 \mathrm{~cm})$, number of suckers per plant (15.8), days taken for planting to shooting (300 days), days taken for shooting to harvest (107 days) and total crop duration (407 days) and yield characters like bunch weight $(23.0 \mathrm{~kg})$, number of hands per bunch (14.6), number of fingers per bunch (254.2), number of fingers per hand (18.9) and finger traits like finger length $(13.1 \mathrm{~cm})$. The other intraclones namely Motta Pooovan and PKNNR also needs further evaluation. The present study it was concluded that Vellapalayankodan recorded the highest values in all the vegetative, bunch, fingers and quality traits and also it is highly suitable for Kerala condition.
\end{abstract}

\section{Introduction}

Banana (Musa spp.) is one of the most important fruit crops of India next to mango. Banana (Musa spp.) is grown in India on $0.796 \mathrm{M}$ ha, contributing 27.57 million tonnes of banana (NHB database 2014). In Kerala, it is the leading fruit crops, being cultivated in larger area and production. Biodiversity of banana cultivars which consist of triploids is complex especially 'Palayankodan' with combination of different degrees of expression of the parental species. In Kerala, several landraces of Palayankodan were available and cultivated in different parts, known in different names.

Palayankodan (AAB group) comprises several popular dessert types of which 'Palayankodan' syn. 'Mysore Poovan' is the most widely cultivated single clone, because of its drought tolerance and suitability for ratooning. The vast difference in the agroclimatic conditions in which the clone is grown and the fact that India is the original home of the genomic group are likely to 
generate numerous mutants in this clone. However, only one mutant namely 'Motta Poovan' has been reported so far. The present investigation was aimed at assessing the intraclonal variation, if any, in banana clone 'Palayankodan' with respect to growth, yield and quality traits.

\section{Materials and Methods}

The present study was carried out at Department of Pomology and Floriculture, College of Agriculture, Vellayani, Thiruvananthapuram, Kerala. A total of six Palayankodan intraclones were assembled from different sources and maintained at Instructional Farm (Table 1). The experiment was laid out in Randomized Block Design (RBD) with five replications as per the method was suggested by Panse and Sukhatme (1967). The cultural practices as per the Package of Practices Recommendation of KAU were followed (KAU, 1996).

Data on the vegetative characters like plant height $(\mathrm{cm})$, pseudostem girth $(\mathrm{cm})$, number of leaves per plant, number of suckers per plant, days taken for planting to shooting, days taken for shooting to harvesting and total crop duration (days) were recorded. Bunches were harvested when they fully mature and traits like bunch weight $(\mathrm{kg})$, number hands per bunch, number of fingers per hand, number of fingers per bunch and hand weight $(\mathrm{kg})$ were recorded.

From the bunch, the middle finger in the top row of the second hand (Gottriech et al., 1964) was sampled to record length $(\mathrm{cm})$, girth $(\mathrm{cm})$, weight $(\mathrm{g})$ and volume of finger (cc). Sugar/acid ratio, pulp/peel ratio and shelf life of fruit were also recorded. The chemical analysis of the fruits was done with ripe fruits. Total soluble solids (TSS) content $\left({ }^{0}\right.$ Brix $)$ of the fruit was recorded with hand refractometer (A.O.A.C., 1984) and expressed in percentage. Total sugars, reducing sugars and titrable acidity content were determined by using standard estimation technique (Ranganna, 1986).

\section{Results and Discussion}

In six intraclones of the 'Palayankodan' certain salient differences were observed with respect to the growth, yield and quality traits (Table 2). In the present study results revealed that Vellapalayankodan recorded the highest plant height $(417.2 \mathrm{~cm})$ whereas the lowest plant height was observed in Motta Poovan $(264.2 \mathrm{~cm})$. The same trend was noticed in girth also. Pseudostem girth observed the highest in Vellapalayankodan $(96.10 \mathrm{~cm})$ while Chandra Bale $(56.50 \mathrm{~cm})$ showed the minimum girth. The growth habit, strong overlapping of functional leaves, height of the plant and long crop duration are involved in the growth of pseudostem (Jacob, 1952). There was significant variance among the Palayankodan intraclones.

The maximum number of leaves per plant was recorded in Pisang Ceylon (11.20), which was significantly superior to other Palayankodan intraclones. The lowest number of leaves per plant was observed in PKNNR (6.80) followed by Chandra Bale (7.20). Rajeevan (1985) reported that leaf production was continuous still shooting in banana. Retention of leaves at functional level is a clonal trait which is influenced to some extent by seasonal difference. According to Stover and Simmonds (1987), growth in height and circumference of the pseudostem is closely related to foliar growth, since the pseudostem consists of overlapping of leaf sheaths. Number of suckers per plant recorded the highest in Vellapayankodan (15.8) and the lowest was noticed in Chandra Bale (6.2). Sreerangaswamy et al., (1980) reported that banana though clonally propagated plants showed significant variation in vegetative 
characters such as plant height, pseudostem girth and suckers per plant within the populations. Mean values of the crop duration of six Palayankodan ecotypes varied significantly (Table 3). Among the Palayankodan ecotypes evaluated, the maximum days taken for planting to shooting was recorded in Vellapalayankodan (300.0 days) which was significantly superior to other Palayankodan intraclones. The minimum days was recorded in PKNNR (205.2 days). The maximum days taken for shooting to harvesting were observed in Vellapalayankodan (107.0 days) whereas the lowest duration was noticed in Chandra Bale (90.6 days).

The highest total crop duration was found in Vellapalayankodan (407.0 days) and the minimum duration was observed in PKNNR (301.2 days). Simmonds (1962) reported that varietal characters and growing conditions were influence the crop duration in banana. Crop duration of banana is very much influenced by agroclimatic conditions and seasonal variation (Valsalakumari, 1985). Rajeevan (1985) reported that significant variation in the crop duration was noticed among the Palayankodan ecotypes.

The bunch characters such as bunch weight, number of hands per bunch, number of fingers per hand, hand weight and number of fingers per bunch varied significantly (Table 4). Vellapalayankodan $(23.0 \mathrm{~kg})$ produced the heaviest bunch followed by the Palode Palayankodan which recorded a bunch weight of $20.10 \mathrm{~kg}$ whereas the lowest bunch weight was found in Motta Poovan $(10.6 \mathrm{~kg})$.

As regards the number of hands per bunch, Vellapalayankodan (14.60) recorded the highest value and the lowest number of hands per bunch was observed in Pisang Ceylon
(10.20). The same trend was noticed in number of fingers per bunch, number of hands per bunch traits also. Vellapalayankodan (254.20) recorded the highest number of fingers per bunch and the lowest was observed in Pisang Ceylon (145.80).

The maximum number of fingers per hand was found in Vellapalayankodan (18.9) whereas the lowest value was in Pisang Ceylon of 14.30. Hand weight recorded the highest in Palode Palayankodan (2.80 kg) whereas the lowest hand weight was found in Motta Poovan $(1.50 \mathrm{~kg})$. This might be due to clonal variation. Simmonds (1962) reported that hands per bunch in banana were affected by environmental factors.

Teaotia et al., (1970) stated that bunch yield was strongly correlated with pseudostem circumference and its contribution to variation in yield. Babu (2001) reported that variation in bunch weight due to change in location or inherent genetic variations. Clones have been reported to show difference in their performance under different agroclimatic conditions (KAU, 1984). Joseph (2017) reported that nendran bunch weight was differed depends on ecotypes variation.

Of the physical attributes studied, all the intraclones differed significantly in respect to length, girth, weight and volume of finger (Table 5). Among the Palayankodan intraclones studied, Vellapalayankodan $(13.1 \mathrm{~cm})$ recorded the highest finger length whereas the lowest length was found in Motta Poovan $(8.40 \mathrm{~cm})$ followed by Chandra Bale $(9.10 \mathrm{~cm})$. Pisang Ceylon $(10.90 \mathrm{~cm})$ recorded the highest finger girth followed by Vellapalayankodan $(10.50 \mathrm{~cm})$ and the lowest girth was observed in Motta Poovan (8.10 $\mathrm{cm})$. 
Table.1 Intraclones name, types, ploidy and genomic composition of Palayankodan ecotypes

\begin{tabular}{|c|l|l|l|l|}
\hline Sl. No. & \multicolumn{1}{|c|}{ Ecotypes } & Type & Ploidy & $\begin{array}{c}\text { Genomic } \\
\text { Composition }\end{array}$ \\
\hline 1. & Palode Palayankodan & Dessert & $3 \mathrm{x}$ & AAB \\
\hline 2. & PKNNR & Dessert & $3 \mathrm{x}$ & AAB \\
\hline 3. & Chandra Bale & Dessert & $3 \mathrm{x}$ & AAB \\
\hline 4. & Pisang Ceylon & Dessert & $3 \mathrm{x}$ & AAB \\
\hline 5. & Motta Poovan & Dessert & $3 \mathrm{x}$ & AAB \\
\hline 6. & Vellapalayankodan & Dessert & $3 \mathrm{x}$ & AAB \\
\hline
\end{tabular}

Table.2 Mean values of the vegetative traits of Palayankodan intraclones of banana

\begin{tabular}{|l|c|c|c|c|}
\hline \multicolumn{1}{|c|}{ Ecotypes } & $\begin{array}{c}\text { Plant height } \\
\text { (cm) }\end{array}$ & $\begin{array}{c}\text { Pseudostem } \\
\text { girth } \mathbf{( c m )}\end{array}$ & $\begin{array}{c}\text { Number of } \\
\text { leaves per } \\
\text { plant }\end{array}$ & $\begin{array}{c}\text { Number of } \\
\text { suckers per plant }\end{array}$ \\
\hline Palode Palayankodan & 313.20 & 67.80 & 10.00 & 11.60 \\
\hline PKNNR & 278.40 & 57.10 & 6.80 & 8.40 \\
\hline Chandra Bale & 292.60 & 56.50 & 7.20 & 6.80 \\
\hline Pisang Ceylon & 300.60 & 60.80 & 11.20 & 6.20 \\
\hline Motta Poovan & 264.20 & 56.60 & 7.60 & 7.60 \\
\hline Vellapalayankodan & 417.20 & 96.10 & 8.40 & 15.80 \\
\hline SEd & 23.72 & 6.35 & 0.77 & 1.54 \\
\hline CD (P=0.05\%) & 60.94 & 16.29 & 1.79 & 3.88 \\
\hline
\end{tabular}

Table.3 Crop duration of Palayankodan intraclones of banana

\begin{tabular}{|l|c|c|c|}
\hline \multicolumn{1}{|c|}{ Ecotypes } & $\begin{array}{c}\text { Days taken from } \\
\text { planting to } \\
\text { shooting (days) }\end{array}$ & $\begin{array}{c}\text { Days taken from } \\
\text { shooting to } \\
\text { harvesting (days) }\end{array}$ & $\begin{array}{c}\text { Total crop } \\
\text { duration (days) }\end{array}$ \\
\hline Palode Palayankodan & 227.40 & 93.00 & 320.40 \\
\hline PKNNR & 205.20 & 95.00 & 301.20 \\
\hline Chandra Bale & 226.00 & 90.60 & 315.20 \\
\hline Pisang Ceylon & 219.80 & 92.80 & 312.60 \\
\hline Motta Poovan & 300.00 & 107.00 & 407.00 \\
\hline Vellapalayankodan & 209.60 & 104.80 & 314.40 \\
\hline SEd & 14.24 & 2.81 & 15.98 \\
\hline CD (P=0.05\%) & 36.58 & 7.32 & 40.97 \\
\hline
\end{tabular}


Table.4 Bunch characters of Palayankodan intraclones of banana

\begin{tabular}{|l|c|c|c|c|c|}
\hline \multicolumn{1}{|c|}{ Ecotypes } & $\begin{array}{c}\text { Bunch } \\
\text { weight } \\
\text { (kg) }\end{array}$ & $\begin{array}{c}\text { Number of } \\
\text { hands per } \\
\text { bunch }\end{array}$ & $\begin{array}{c}\text { Number of } \\
\text { fingers per } \\
\text { bunch }\end{array}$ & $\begin{array}{c}\text { Number of } \\
\text { fingers per } \\
\text { hand }\end{array}$ & $\begin{array}{c}\text { Hand } \\
\text { weight } \\
\text { (kg) }\end{array}$ \\
\hline Palode Palayankodan & 20.10 & 11.40 & 207.8 & 18.2 & 2.80 \\
\hline PKNNR & 12.90 & 10.60 & 179.4 & 16.9 & 2.00 \\
\hline Chandra Bale & 14.10 & 10.40 & 179.0 & 17.2 & 1.80 \\
\hline Pisang Ceylon & 16.40 & 10.20 & 145.8 & 14.3 & 2.20 \\
\hline Motta Poovan & 10.60 & 10.60 & 172.2 & 15.8 & 1.50 \\
\hline Vellapalayankodan & 23.00 & 14.60 & 254.2 & 18.9 & 1.90 \\
\hline SEd & 2.12 & 0.81 & 17.41 & 0.74 & 0.17 \\
\hline CD (P=0.05\%) & 5.33 & 2.13 & 44.74 & 1.78 & 0.39 \\
\hline
\end{tabular}

Table.5 Finger traits of Palayankodan ecotypes of banana

\begin{tabular}{|l|c|c|c|c|c|}
\hline \multicolumn{1}{|c|}{ Ecotypes } & $\begin{array}{c}\text { Length of } \\
\text { finger } \\
\text { (cm) }\end{array}$ & $\begin{array}{c}\text { Finger } \\
\text { girth }\end{array}$ & $\begin{array}{c}\text { Weight of } \\
\text { finger }(\mathbf{g})\end{array}$ & $\begin{array}{c}\text { Volume of } \\
\text { finger (cc) }\end{array}$ & $\begin{array}{c}\text { Pulp/peel } \\
\text { ratio }\end{array}$ \\
\hline Palode Palayankodan & 13.00 & 10.40 & 94.10 & 88.40 & 3.39 \\
\hline PKNNR & 11.30 & 10.30 & 107.30 & 101.70 & 3.42 \\
\hline Chandra Bale & 9.10 & 8.30 & 109.20 & 97.60 & 3.45 \\
\hline Pisang Ceylon & 11.80 & 10.90 & 97.60 & 92.60 & 3.30 \\
\hline Motta Poovan & 8.40 & 8.10 & 96.70 & 92.00 & 3.58 \\
\hline Vellapalayankodan & 13.10 & 10.50 & 90.10 & 82.50 & 2.53 \\
\hline SEd & 1.21 & 0.84 & 13.81 & 13.52 & 0.25 \\
\hline CD (P=0.05\%) & 3.08 & 2.08 & 35.52 & 34.74 & 0.54 \\
\hline
\end{tabular}

Table.6 Mean values of the quality traits of Palayankodan intraclones of banana

\begin{tabular}{|l|c|c|c|c|c|c|}
\hline \multicolumn{1}{|c|}{ Ecotypes } & $\begin{array}{c}\text { Total soluble } \\
\text { solids (TSS) } \\
\text { ( B } \mathbf{d i x})\end{array}$ & $\begin{array}{c}\text { Tritable } \\
\text { Acidity } \\
\mathbf{( \% )}\end{array}$ & $\begin{array}{c}\text { Total } \\
\text { sugars } \\
\mathbf{( \% )}\end{array}$ & $\begin{array}{c}\text { Reducing } \\
\text { sugars } \\
(\boldsymbol{\%})\end{array}$ & $\begin{array}{c}\text { Sugar/acid } \\
\text { ratio }\end{array}$ & $\begin{array}{c}\text { Shelf life } \\
\text { of fruit } \\
\text { (days) }\end{array}$ \\
\hline Palode Palayankodan & 21.30 & 0.41 & 17.21 & 17.05 & 46.60 & 6.72 \\
\hline PKNNR & 27.90 & 0.40 & 17.33 & 17.09 & 44.70 & 5.81 \\
\hline Chandra Bale & 27.40 & 0.42 & 17.29 & 17.06 & 43.70 & 5.88 \\
\hline Pisang Ceylon & 23.40 & 0.38 & 17.25 & 17.08 & 47.10 & 5.45 \\
\hline Motta Poovan & 27.20 & 0.44 & 16.57 & 16.40 & 37.40 & 5.24 \\
\hline Vellapalayankodan & 25.40 & 0.24 & 16.60 & 16.39 & 68.53 & 8.65 \\
\hline SEd & 0.84 & 0.08 & 0.38 & 0.27 & 4.35 & 0.69 \\
\hline CD (P=0.05\%) & 2.14 & 0.11 & 0.81 & 0.52 & 11.20 & 1.68 \\
\hline
\end{tabular}


The highest finger weight was observed in Chandra Bale (109.20 g) whereas the lowest finger weight was found in Vellapalayankodan $(90.10 \mathrm{~g})$. The highest fruit volume $(101.70 \mathrm{cc})$ was observed in PKNNR and the lowest was in Vellapalayankodan $(82.50 \mathrm{cc})$. Among the Palayankodan intraclones the highest pulp/peel ratio was found in Motta Poovan (3.60) and the lowest was in Vellapalayankodan (2.53). Variation in finger length described as varietal characters (Lenka et al., 2002). Rajeevan and Mohanakumaran (1993) observed that yield traits varied significantly among the Palayankodan accessions of Kerala. Joseph (2017) stated that finger characters varied among the nendran ectoypes of Kerala.

The quality characters of six Palayankodan ecotypes like TSS, total sugars, reducing sugars, sugar/acid ratio and shelf life of fruit varied significantly (Table 6). In the present study, among the Palayankodan intraclones TSS recorded the highest in PKNNR (27.90 ${ }^{0}$ Brix) whereas the lowest was found in Palode Palayankodan (21.34 ${ }^{0}$ Brix $)$. Rajamony et al., (1994) found that TSS varied from 22.0 per cent (Motta Poovan) to 30.0 per cent (Kodapanilla Kunnan) under Thrissur condition. There was no significant difference observed among the Palayankodan intraclones with respect to tritable acidity. The highest acidity was recorded in Motta Poovan (0.44 $\%$ ) and the lowest value was observed in Vellapalayankodan $(0.24 \%)$. Acidity of fruits has been described as varietal traits in banana (KAU, 1984; Rajeevan, 1985). There was no significant difference in total sugars among the Palayankodan intraclones studied. The maximum total sugar was recorded in Chandra Bale $(17.29 \%)$ whereas the lowest value was observed in Motta Poovan (16.57 $\%)$. The reducing sugars found the highest in PKNNR (17.09 \%) and the lowest value was observed in Vellapalayankodan (16.39 \%).
The maximum sugar/acid ratio was observed in Vellapalayankodan (68.53) which was significantly superior to other Palayankodan intraclones. The lowest value was recorded in Motta Poovan (37.35). The highest shelf life (8.65 days) was recorded in Vellapalayankodan whereas the lowest shelf life was found in Motta Poovan (5.24 days). From the present study it was concluded that the Palayankodan ecotypes like 'Motta Pooovan' and PKNNR were needs further evaluation and used for breeding programme.

\section{References}

A.O.A.C. (1984). Official methods of analysis. Association of official analytical, chemist, $10^{\text {th }}$ Edition, Washington D.C.

Babu N. (2001). Performance of some genotypes of banana under foot hills of Nagaland. New Agriculturist, 12 (1): 13-16.

Gottriech M., Bradu D, Halery. (1964). A simple method for determining average fruit weight. Ktvani, 14: 161-162.

Jacob KC. (1952). Madras banana - A monograph. Government Press, Madras.

Joseph AV. (2017). Performance evaluation of ecotypes of banana (Musa AAB plantain subgroup), M.Sc. (Hort.) thesis submitted to the Kerala Agricultural University, Thrissur, Kerala.

KAU. (1984). Research Report 1982-1983. Directorate of Research, Kerala Agricultural University, Thrissur.

KAU. (1996). Package of Practices Recommendations: Crops 1996. $11^{\text {th }}$ Edition, Directorate of Extension, Kerala Agricultural University, Thrissur.

Lenka PC, Dash DK, Ray DP, Jamal S. (2002). Evaluation of banana genotypes under agroclimatic condition of Orissa. 
Global Conference on Banana and Plantain, October 28 - 31, 2002. (Eds. Singh, H.P. and Dadlani, N. K.). Association of the Improvement in Production and Utilization of Banana, Bangalore, p.37

Panse VG, Sukhatme PV. (1967). Statistical Methods for Agricultural Workers, New Delhi.

Rajamony L, George KC, Anitha N, Radhakrishnan TC. (1994). Assessment of banana (Musa spp.) clones of AAB groups based on stability and adaptation. Indian Journal of Agricultural Science, 64: 521-526

Rajeevan PK. (1985). Intraclonal variations and nutritional studies in banana cv.

Palayankodan. Ph.D, Thesis submitted to KAU, Thrissur, Kerala.

Rajeevan PK, Mohanakumaran N. (1993). Intraclonal variation in Musa (AAB) Mysore. South Indian Horticulture, 41: 307-314.

Ranganna S. (1986). Hand book of analysis and quality control for fruit and vegetable products. $2^{\text {nd }}$ edition, Tata Mc Graw Hill Publishers Company Limited, New

Delhi.
Indian Council of Agricultural Research, New Delhi.

Simmonds NW. (1962). The Evaluation of the Bananas. Longmans, Green and Company Limited, London.

Sreerangasamy SR, Sambandamurthi S, Murugesan M. (1980). Genetic analysis in banana. Proceedings of National Seminar on Banana Production Technology, July 10-12, 1980. (Eds. Muthukrishnan, C.R. and Abdulkhader, J.B.M.). Tamil Nadu Agricultural University, Coimbatore, p. 50-56

Stover RH, Simmonds NW. (1987). Bananas. Third edition, Longman Scientific and Technical, Harlow, Esse, England.

Teaotia SS, Bhati DR, Phogat PS. (1970). Simple partial and multiple correlation of quantitative characters of banana. Progressive Horticulture, 1: $17-24$.

Valsalakumari PK. (1985). Cytotaxonomical studies on banana cultivars. Ph.D., Thesis submitted to Kerala Agricultural University, Thrissur, Kerala.

Rao VNM. (1998). Banana. Third Edition,

\section{How to cite this article:}

Rajamanickam. C. and Rajmohan. K. 2020. Intraclonal Variation in Musa (AAB) Palayankodan. Int.J.Curr.Microbiol.App.Sci. 9(06): 269-275. doi: https://doi.org/10.20546/ijcmas.2020.906.034 